\title{
Comparison of the Mental Status of COVID-19 Intensive Care Unit and General Intensive Care Unit Staff
}

\author{
COVID-19 Yoğun Bakım Ünitesi ve Genel Yoğun Bakım Ünitesi Personelinin \\ Ruhsal Durumunun Karşılaştırılması
}

\section{Fatma ÇELIK \\ (i) 0000-0003-0192-0151 \\ Recai DAĞLI \\ (D) 0000-0002-6364-0545}

Department of Anesthesiology and Reanimation, Kırşehir Ahi Evran University Faculty of Medicine, Kırşehir, Turkey

\section{Corresponding Author Sorumlu Yazar \\ Fatma ÇELIK \\ drftmcelik@gmail.com}

\begin{abstract}
Aim: The coronavirus disease 2019 (COVID-19) pandemic may predispose front-line intensive care staff to experience mental health problems. The aim of this study was to compare the COVID-19 fear experienced by COVID-19 intensive care unit staff and general intensive care unit staff, and the effects of this fear on mental health.

Material and Methods: In this cross-sectional study, a total of 156 participants, $90(57.7 \%)$ participants from the COVID-19 intensive care unit and 66 (42.3\%) from the general intensive care unit, were included. A printed questionnaire consisting of the Fear of COVID-19 Scale (FCV-19S), Depression Anxiety Stress Scale (DASS-21), and demographic data were used. Results: Female gender, being a nurse, and working in COVID-19 intensive care unit, were associated with higher depression, anxiety, and stress scores. A significant relationship was found between fear of COVID-19 and depression $(\rho=0.399, p=0.044)$, anxiety $(\rho=0.456$, $p=0.019)$, and stress $(\rho=0.418, p=0.033)$. Furthermore, as compared to general intensive care unit staff, COVID-19 intensive care unit staff who may have high-risk contact were approximately twice times more likely to experience anxiety and fear of COVID-19 and 3.5 times more likely to suffer from depression and stress.

Conclusion: The COVID-19 pandemic has adversely affected the mental health of intensive care staff. Attention should be paid to the mental health of females and nurses working in the COVID-19 intensive care unit. The mental health of intensive care workers should be supported to protect the health workforce.
\end{abstract}

Keywords: Anxiety; COVID-19; depression; fear; mental health; intensive care.

ÖZ

Amaç: Koronavirüs hastalığ1 2019 (coronavirus disease 2019, COVID-19) pandemisi, ön saflardaki yoğun bakım personelini ruhsal sağlık sorunları yaşamaya yatkın hale getirebilir. Bu çalışmanın amacı, COVID-19 yoğun bakım ünitesi personeli ile genel yoğun bakım ünitesi personelinin yaşadığı COVID-19 korkusunu ve bu korkunun ruh sağlıkları üzerindeki etkilerini karşıllaştırmaktır.

Gereç ve Yöntemler: Bu kesitsel çalışmaya COVID-19 yoğun bakım ünitesinden $90(\% 57,7)$ katılımcı ve genel yoğun bakım ünitesinden $66(\% 42,3)$ katılımcı olmak üzere toplam 156 katılımcı dahil edildi. COVID-19 Korku Ölçeği (Fear of COVID-19 Scale, FCV-19S), Depresyon Anksiyete Stres Ölçeği (Depression Anxiety Stress Scale, DASS-21) ve demografik verilerden oluşan basılı bir anket kullanıldı.

Bulgular: Kadın cinsiyet, hemşire olmak ve COVID-19 yoğun bakım ünitesinde çalışmak daha yüksek depresyon, anksiyete ve stres puanları ile ilişkili idi. COVID-19 korkusu ile depresyon $(\rho=0,399 ; p=0,044)$, kayg $1(\rho=0,456 ; p=0,019)$ ve stres $(\rho=0,418 ; p=0,033)$ arasinda anlamlı bir ilişki bulundu. Ayrıca, genel yoğun bakım ünitesi personeline kıyasla, yüksek temas riski olan COVID-19 yoğun bakım ünitesi personelinin, anksiyete ve COVID-19 korkusu yaşama olasılığı yaklaşık iki kat, depresyon ve stresten muzdarip olma olasılığ 3,5 kat daha fazlaydi.

Sonuç: COVID-19 pandemisi, yoğun bakım personelinin ruh sağlığını olumsuz etkilemiştir. COVID-19 yoğun bakım ünitesinde çalışan kadın ve hemşirelerin ruh sağlığına dikkat edilmelidir. Yoğun bakım çalışanlarının ruh sağlığı, sağlık iş gücünün korunması için desteklenmelidir.

Received / Geliş Tarihi : 13.04 Accepted / Kabul Tarihi : 16.08.2021 Available Online /

Çevrimiçi Yayın Tarihi : 20.08.2021

Anahtar kelimeler: Anksiyete; COVID-19; depresyon; korku; ruh sağlı̆̆ı; yoğun bakım. 


\section{INTRODUCTION}

The World Health Organization (WHO) defined the novel coronavirus disease 2019 (COVID-19) as a pandemic in March 2020. WHO has determined protecting the mental well-being of healthcare workers who care for people with COVID-19 as a necessity to sustain the health workforce in the long term (1).

During past pandemics, healthcare workers experienced anxiety, stress, depression, and fear for various reasons such as intense work stress, loneliness, social isolation, fear of getting infected, and fear of infecting others. It has even been reported that these adverse psychological effects may continue for months or years (2-5).

Global health systems have struggled to fight as a result of the rapid spread of the COVID-19 pandemic (6). During the COVID-19 pandemic, patients' intensive care support needs also increased (7). Due to the nature of their profession, healthcare professionals are always at high risk of getting infected with infectious diseases such as COVID-19. While working in an intensive care setting, continuous close contact, and repeated contact with patients is inevitable (8). Intensive care workers are exposed to heavy workload, long-term fatigue, and the threat of infection for their family and their safety $(3,6,7)$. They also face uncertainty about the duration of a pandemic, capacities of proven therapies, personal protective equipment, and health resources. Healthcare professionals may experience psychological distress due to providing direct care to COVID-19 patients, having a relative or someone familiar who is sick or critically ill, and being quarantined (9). These conditions can create high levels of stress, fear, and anxiety in employees and may expose them to permanent adverse psychological effects. Therefore, healthcare workers are at risk of subclinical mental health disorder symptoms and longterm burnout (7).

Despite meticulous global combat efforts, COVID-19 continues to rise around the world. It is substantial to evaluate the mental status of intensive care workers to take the necessary measures and make improvements to protect the health workforce in the fight against COVID-19.

In this study, we aimed to evaluate the fear of COVID-19 situation of COVID-19 intensive care unit (COVID-19 ICU) and general intensive care unit (ICU) staff and to compare the effect of this fear on their mental health.

\section{MATERIAL AND METHODS}

\section{Participants and Procedures}

This cross-sectional study was conducted after the approval of the Kırşehir Ahi Evran University Ethics Committee (24.06.2020, 09-63). We planned our research according to current Helsinki guidelines. The hospital has both the $3^{\text {rd }}$ line COVID-19 ICU, where the treatment and care of COVID-19 patients are provided and the ICU, where patients who are not infected with COVID-19 are treated. The study was conducted on 156 personnel working in these two intensive care units. Doctor, nurse, and assistant health personnel working in intensive care units were asked to fill out printed questionnaires between 1 July and 10 July 2020. Within the scope of COVID-19 contact isolation rules and protection measures, the responsible researcher informed the participants about the research. Signed, enlightened consents of the participants were obtained. Volunteers diagnosed with psychological and cognitive disorders and currently receiving medical support were excluded from the study.

\section{Screening Questionnaire}

The questionnaire form used in this study consists of 3 parts: socio-demographic data, Fear of COVID-19 Scale (FCV-19S), and Depression Anxiety Stress Scales (DASS-21).

Socio-demographic Data: These data include age, gender, profession (doctor, nurse, assistant healthcare personnel), working year $(<5,6-10,11-15\rangle$,15 years $)$, and marital status (single, married, married-with children).

Fear of COVID-19 Scale (FCV-19S): Ahorsu et al. (10) have developed the FCV-19S scale. It is a one-dimensional scale with a 5-point Likert-type rating system consisting of seven items (1: Strongly disagree to 5: Strongly agree). A minimum of 1 point and a maximum of 5 points are given for each question. The total score is calculated by adding the scores of 7 items (between 7 and 35 points). In our study, the Turkish scale adaptation of FCV-19S by Satici et al. (11) was used.

Depression Anxiety Stress Scales (DASS-21): This scale has been developed from the DASS-42 with 42-item (12). DASS-21 consists of three sub-dimensions (depression, anxiety, and stress) and 21 items. There are 7 items in each sub-dimension. The scale has a 4-point Likert-type rating system (0: Never to 3: Always). Each sub-dimensions score is calculated by adding each item score. Since the DASS-21 scale is developed as a short form of DASS-42, it is calculated by multiplying each sub-dimension score by two. DASS-21 scores are interpreted as follows: Depression: normal (0-9), mild (10-13), moderate (14-20), severe (21-27), and extremely severe (28-42); Anxiety: normal (0-7), mild (8-9), moderate (10-14), severe (15-19), and extremely severe (20-42); Stress: Normal (0-14), mild (15-18), medium (19-25), severe (26-33), and extremely severe (34-42). In this study, Turkish scale adaptation by Yilmaz et al. (13) was used.

\section{Statistical Analysis}

Statistical analyses were performed using SPSS v.21.0 software (IBM SPSS Statistics for Windows, Version 21.0. Armonk, NY: IBM Corp.). The normality assumption was tested with Kolmogorov-Smirnov and Shapiro-Wilk tests. Since the study is a questionnaire study, kurtosis and skewness coefficients were also taken into account in the test of the normality assumption. Descriptive statistics of variables that provide normality assumption were given as mean \pm standard deviation (min-max); median $\left(25^{\text {th }}-75^{\text {th }}\right.$ percentile) were given for variables not provide normality assumption. Categorical variables were summarized as frequency and percentage. Group comparisons based on the total scores were made by using the Mann-Whitney U and Kruskal-Wallis tests. When a significant difference was found between the groups by the Kruskal-Wallis test, the Mann-Whitney U test was used as the post hoc test. Chi-square and Fisher-Freeman-Halton tests were used to compare categorical variables. The relationship between fear of COVID-19 and anxiety, depression, and stress were tested with Spearman correlation analysis. Multivariate analyzes for fear of COVID-19, depression, anxiety, and stress were performed using the ordinal logistic regression model. The reliability of the scale was conducted using Cronbach's alpha coefficient. 


\section{RESULTS}

\section{Reliability of the DASS-21 and FCV-19S}

Cronbach's alpha values of the depression, anxiety, and stress sub-dimensions of the DASS-21 scale were determined as $0.810,0.800$, and 0.755 , respectively, in the study of Yilmaz et al (13). In our study, Cronbach's alpha values of DASS-21 sub-dimensions were found to be $0.889,0.848$, and 0.827 , respectively. Cronbach's alpha value of the FCV-19S scale was 0.840 in the study by Satici et al. (11). The Cronbach's alpha value of FCV-19S in our study was found as 0.916 .

\section{Participants' Characteristics}

One hundred fifty-six employees voluntarily participated in the study among 162 employees working in our hospital's intensive care units. There were $90(57.7 \%)$ participants from the COVID-19 ICU and 66 (42.3\%) from the ICU. Descriptive statistics and group comparisons of the demographic characteristics of COVID-19 ICU and ICU personnel are given in Table 1.

\section{Comparison of COVID-19 Fears}

The results for FCV-19S are shown in Table 2. The effect of gender on fear of COVID-19 was found to be significant $(\mathrm{p}=0.001)$. FCV-19S value of male staff was found higher than female staff (23 (16.0-27.0) vs. 18.5 (13.75-22.0)). Although the FCV-19S scores of the COVID-19 ICU staff group were slightly higher in both male and female compared to the ICU group, this difference was not significant $(\mathrm{p}=0.381, \mathrm{p}=0.104$, respectively).

\section{Analysis of Psychological Features: DASS-21}

The statistically comparisons of DASS-21 depression, anxiety, and stress scores are shown in Table 3 . When the scores in our and similar studies are examined, it will be more appropriate to interpret both statistically and clinically. Although a statistically significant difference was found in some comparisons (married-with children and nurse anxiety, etc.) of COVID-19 ICU and ICU; when evaluated according to subgroups as depression, anxiety,

Table 1. Comparison of demographic data of COVID-19 ICU and ICU staff

\begin{tabular}{|c|c|c|c|c|}
\hline & Total $(n=156)$ & COVID-19 ICU (n=90) & ICU $(n=66)$ & $\mathbf{p}$ \\
\hline Age (years), mean \pm SD (min-max) & $32.61 \pm 8.78(18-57)$ & $32.98 \pm 8.87(20-57)$ & $32.10 \pm 8.70(18-52)$ & 0.537 \\
\hline \multicolumn{5}{|l|}{ Gender, n (\%) } \\
\hline Male & $66(42.3 \%)$ & $39(59.1 \%)$ & $27(40.9 \%)$ & \multirow{2}{*}{0.762} \\
\hline Female & $90(57.7 \%)$ & $51(56.7 \%)$ & $39(43.3 \%)$ & \\
\hline \multicolumn{5}{|l|}{ Marital Status, n (\%) } \\
\hline Single & $64(41.0 \%)$ & $38(59.4 \%)$ & $26(40.6 \%)$ & \multirow{3}{*}{0.898} \\
\hline Married (no children) & $15(9.6 \%)$ & $9(60.0 \%)$ & $6(40.0 \%)$ & \\
\hline Married (with children) & $77(49.4 \%)$ & $43(55.8 \%)$ & $34(44.2 \%)$ & \\
\hline \multicolumn{5}{|l|}{ Profession, n (\%) } \\
\hline Doctor & $27(17.3 \%)$ & $15(55.6 \%)$ & $12(44.4 \%)$ & \multirow{3}{*}{0.967} \\
\hline Nurse & $96(61.5 \%)$ & $56(58.3 \%)$ & $40(41.7 \%)$ & \\
\hline Assistant healthcare personnel & $33(21.2 \%)$ & $19(57.6 \%)$ & $14(42.4 \%)$ & \\
\hline \multicolumn{5}{|l|}{ Working year, n (\%) } \\
\hline $0-5$ & $87(39.2 \%)$ & $48(55.2 \%)$ & $39(44.8 \%)$ & \multirow{4}{*}{0.874} \\
\hline $6-10$ & $57(25.7 \%)$ & $33(57.9 \%)$ & $24(42.1 \%)$ & \\
\hline $11-15$ & $41(18.5 \%)$ & $25(61.0 \%)$ & $16(39.0 \%)$ & \\
\hline$>15$ & $37(16.7 \%)$ & $23(62.2 \%)$ & $14(37.8 \%)$ & \\
\hline
\end{tabular}

Table 2. Comparison of COVID-19 ICU and ICU staff fears based on FCV-19S scores

\begin{tabular}{|c|c|c|c|c|}
\hline & Total $(n=156)$ & COVID-19 ICU (n=90) & ICU $(n=66)$ & $\mathbf{p}$ \\
\hline \multicolumn{5}{|l|}{ Gender } \\
\hline Male & $23(16.0-27.0)$ & $23(19.0-27.0)$ & $22(12.0-27.0)$ & 0.381 \\
\hline Female & $18.5(13.75-22.0)$ & $19(14.0-23.0)$ & $17(11.0-21.0)$ & 0.104 \\
\hline $\mathbf{p}$ & 0.001 & 0.009 & 0.035 & \\
\hline \multicolumn{5}{|l|}{ Marital Status } \\
\hline Single & $20(14.0-24.0)$ & $20.5(15.75-24.0)$ & $18.5(10.75-24.25)$ & 0.503 \\
\hline Married (no children) & $20(17.0-26.0)$ & $22(17.0-25.5)$ & $19(14.5-29.0)$ & 0.776 \\
\hline Married (with children) & $21(14.5-26.0)$ & $22(19.0-27.0)$ & $19.5(12.0-24.25)$ & 0.073 \\
\hline p & 0.407 & 0.198 & 0.867 & \\
\hline \multicolumn{5}{|l|}{ Profession } \\
\hline Nurse & $22(15.0-26.0)$ & $22(17.0-26.0)$ & $19(12.0-25.0)$ & 0.092 \\
\hline Assistant healthcare personnel & $20(14.0-26.0)$ & $18(12.0-24.0)$ & $21(13.0-29.25)$ & 0.553 \\
\hline Doctor & $19(14.0-23.0)$ & $21(19.0-24.0)$ & $19(11.75-20.75)$ & 0.075 \\
\hline p & 0.433 & 0.198 & 0.550 & \\
\hline \multicolumn{5}{|l|}{ Working year } \\
\hline $0-5$ & $18(12.0-23.0)$ & $18.5(15.75-23.0)$ & $15(10.0-23.75)$ & 0.197 \\
\hline $6-10$ & $23(19.0-27.0)$ & $23.5(20.25-26.75)$ & $22(17.0-31.0)$ & 0.633 \\
\hline $11-15$ & $21.5(14.0-26.0)$ & $21(14.5-26.0)$ & $21.5(13.5-25.75)$ & 0.673 \\
\hline$>15$ & $20(14.5-25.0)$ & $21.25(17.5-26.75)$ & $19(10.5-23.5)$ & \\
\hline $\mathbf{p}$ & 0.055 & 0.077 & 0.161 & \\
\hline
\end{tabular}


Table 3. Comparison of DASS-21 scores of COVID-19 ICU and ICU staff

\begin{tabular}{|c|c|c|c|c|c|c|c|c|c|}
\hline & \multicolumn{3}{|c|}{ DASS-21 Depression } & \multicolumn{3}{|c|}{ DASS-21 Anxiety } & \multicolumn{3}{|c|}{ DASS-21 Stress } \\
\hline & COVID-19 ICU & ICU & $\mathbf{p}$ & COVID-19 ICU & ICU & $\mathbf{p}$ & COVID-19 ICU & ICU & p \\
\hline \multicolumn{10}{|l|}{ Gender } \\
\hline Female & $12(4.0-22.0)$ & $4(2.0-8.0)$ & 0.006 & $10(4.0-12.0)$ & $4(2.0-10.0)$ & 0.007 & $16(12.0-22.0)$ & $8(6.0-12.0)$ & $<0.001$ \\
\hline Male & $6(2.0-14.0)$ & $4(2.0-8.0)$ & 0.405 & $2(2.0-6.0)$ & $2(0.0-4.0)$ & 0.134 & $12(6.0-14.0)$ & $8(4.0-14.0)$ & 0.241 \\
\hline $\mathbf{p}$ & 0.012 & 0.509 & & $<0.001$ & 0.028 & & 0.002 & 0.958 & \\
\hline \multicolumn{10}{|l|}{ Marital Status } \\
\hline Single & $9(2.0-20.5)$ & $6(1.5-15.0)$ & 0.360 & $4(2.0-12.0)$ & $2(0.0-8.5)$ & 0.070 & $14(8.0-17.5)$ & $8(4.0-8.5)$ & 0.019 \\
\hline Married (no children) & $6(0.0-16.0)$ & $5(4.0-12.5)$ & 0.864 & $4(2.0-10.0)$ & $6(1.5-18.5)$ & 0.529 & $12(9.0-18.0)$ & $8(7.5-14.0)$ & 0.272 \\
\hline Married(with children) & $8(4.0-16.0)$ & $3(2.0-6.0)$ & 0.001 & $4(2.0-10.0)$ & $2(1.5-6.0)$ & 0.016 & $14(8.0-18.0)$ & $8(4.0-12.0)$ & 0.001 \\
\hline p & 0.634 & 0.144 & & 0.540 & 0.355 & & 0.919 & 0.863 & \\
\hline \multicolumn{10}{|l|}{ Profession } \\
\hline Nurse & $11(4.5-18.0)$ & $4(2.0-7.5)$ & $<0.001$ & $7(4.0-12.0)$ & $2(2.0-7.5)$ & 0.001 & $16(10.5-21.0)$ & $8(4.0-10.0)$ & $<0.001$ \\
\hline Assistant healthcare personnel & $6(2.0-16.0)$ & $4(1.5-14.5)$ & 0.653 & $4(0.0-10.0)$ & $2(0.0-7.0)$ & 0.529 & $12(4.0-20.0)$ & $7(4.0-13.5)$ & 0.377 \\
\hline Doctor & $2(2.0-6.0)$ & $7(4.5-17.5)$ & 0.059 & $2(0.0-6.0)$ & $2(0.0-9.5)$ & 0.867 & $10(6.0-14.0)$ & $12(10.0-16.0)$ & 0.167 \\
\hline p & 0.013 & 0.149 & & 0.002 & 0.660 & & 0.018 & 0.017 & \\
\hline $\mathbf{p}^{(\mathrm{N}-\mathrm{AHP})}$ & 0.231 & 0.741 & & 0.024 & 0.455 & & 0.188 & 0.872 & \\
\hline $\mathbf{p}^{(\mathrm{N}-\mathrm{D})}$ & 0.003 & 0.059 & & 0.002 & 0.494 & & 0.003 & 0.004 & \\
\hline $\mathbf{p}^{\text {(AHP-D) }}$ & 0.286 & 0.347 & & 0.471 & 0.980 & & 0.632 & 0.003 & \\
\hline \multicolumn{10}{|l|}{ Working year } \\
\hline $0-5$ & $7(2.0-22.0)$ & $5(2.0-8.0)$ & 0.288 & $6(2.0-12.0)$ & $2(0.5-9.0)$ & 0.098 & $14(7.5-20.5)$ & $8(4.0-11.5)$ & 0.018 \\
\hline $6-10$ & $4(1.0-9.0)$ & $6(2.0-8.0)$ & 0.192 & $6(4.0-12.0)$ & $2(2.0-8.0)$ & 0.033 & $15(12.0-21.0)$ & $8(6.0-12.0)$ & 0.001 \\
\hline $11-15$ & $7(2.5-16.0)$ & $2(2.0-7.0)$ & 0.156 & $4(2.0-9.5)$ & $2(0.0-7.0)$ & 0.237 & $12(6.5-17.5)$ & $9(5.0-12.0)$ & 0.151 \\
\hline $15+$ & $6(4.0-14.0)$ & $4(1.0-5.0)$ & 0.251 & $4(2.0-12.5)$ & $2(2.0-8.0)$ & 0.239 & $12(6.0-20.5)$ & $10(6.0-14.0)$ & 0.257 \\
\hline p & 0.931 & 0.529 & & 0.433 & 0.768 & & 0.336 & 0.726 & \\
\hline
\end{tabular}

and stress clinical levels (normal, mild, moderate, severe, extremely severe), no clinically significant difference was found between the groups. For example, in the comparison of depression scores of participants married-with children although a significant difference was found between the groups ( 8 (4.0-16.0) vs. 3 (2.0-6.0), $\mathrm{p}=0.001)$; both group scores were $<9$, that is, in the normal group. Similarly, in comparison of anxiety scores (4 (2.0-10.0) vs. 2 (1.5-6.0), $\mathrm{p}=0.016$ ), score of both groups were $<7$, and they were in the normal group. Again, in comparison of nurse anxiety (7 (4.0-12.0) vs. 2 (2.0-7.5), p=0.001) both groups score were $<7$, and they were in the normal group.

COVID-19 ICU female staff were found to have higher depression values than male $(\mathrm{p}=0.012)$. While the effect of working in COVID-19 ICU or ICU on depression values was insignificant in male workers $(p=0.405)$, depression levels of female working in COVID-19 ICU were higher than female healthcare workers working in ICU $(p=0.006)$. Among the personnel of COVID-19 ICU, depression levels of nurses were found to be the highest, while doctors' levels were found to be the lowest $(\mathrm{p}=0.013)$. According to the classification of DASS-21 depression severity (normal, mild, moderate, severe, extremely severe), working in the COVID-19 ICU had a significant effect on the depression levels of the staff ( $p=0.012$, Table 4). It was determined that both COVID-19 ICU and ICU female staff had higher anxiety values than males $(p<0.001, p=0.028$, respectively). COVID-19 ICU female staff had higher anxiety levels than ICU female staff $(p=0.007)$. On the other hand, the effect of working in COVID-19 ICU or ICU on anxiety levels of male staff was insignificant $(p=0.134)$. While the effect of occupational titles on the anxiety values of COVID-19 ICU staff was significant $(\mathrm{p}=0.002)$, the effect on the anxiety values of ICU staff was found to be insignificant $(\mathrm{p}=0.660)$. Among the COVID-19 ICU staff, nurses had the highest anxiety score (Table 3). The relationship between the distribution of the DASS-21 anxiety severity classification and the type of intensive care unit (COVID-19 ICU or ICU) was not statistically significant ( $\mathrm{p}=0.302$, Table 4$)$.

Female staff in COVID-19 ICU had higher stress levels than males $(p=0.002)$. There was no difference between males and females working in ICU in terms of stress level $(\mathrm{p}=0.958)$. Female staff in COVID-19 ICU had higher stress levels than ICU female staff $(p<0.001)$. The effect of the type of intensive care unit on the stress levels of male staff was insignificant $(p=0.241)$. Nurses had the highest stress levels amongst COVID-19 ICU staff ( $p=0.018)$, on the other hand, doctors were the most stressful among ICU staff $(\mathrm{p}=0.017)$. COVID-19 ICU nurses had higher stress levels than ICU nurses $(p<0.001)$. The stress levels of COVID-19 ICU personnel with 0-5 years of working experience, and 6-10 years of working experience were significantly higher than the ICU personnel with the same working years $(\mathrm{p}=0.018, \mathrm{p}=0.001$, respectively, Table 3 ). According to the DASS-21 classification of depression severity, working in the COVID-19 ICU had a significant effect on the stress levels of the staff ( $p=0.008$, Table 4).

Fear of COVID-19, Depression, Anxiety and Stress

The scores of FCV-19S and DASS-21 scales and group comparisons are given in Table 5. The FCV-19S score of the COVID-19 ICU staff group was significantly higher than the ICU staff group ( $\mathrm{p}=0.022)$. DASS-21 depression, anxiety, and stress levels were significantly higher in the COVID-19 ICU staff group than in the ICU group ( $\mathrm{p}=0.011, \mathrm{p}=0.002, \mathrm{p}<0.000$, respectively).

Relationship between Fear of COVID-19 and Depression, Anxiety and Stress Reactions

Spearman's rho coefficients showing the relationship between fear of COVID-19 and DASS-21 depression, anxiety, and stress values were summarized in Table 6. Increasing fear of COVID-19 caused an increase in DASS-21 depression, anxiety, and stress values of ICU workers. The relationship between fear of COVID-19 and depression $(\rho=0.399, p=0.044)$, anxiety $(\rho=0.456, p=0.019)$, stress $(\rho=0.418, p=0.033)$ is positive and significant. 
COVID-19 ICU staff who may have high-risk contact were 3.26 times more likely to experience depression $(\mathrm{OR}=3.26,95 \% \mathrm{CI}=1.595-6.692, \mathrm{p}=0.001), 1.98$ times anxiety $(\mathrm{OR}=1.98,95 \% \mathrm{CI}=1.010-3.892, \mathrm{p}=0.047)$ and 3.61 times stress $(\mathrm{OR}=3.61,95 \% \mathrm{CI}=1.688-7.750, \mathrm{p}=0.001)$ than ICU staff (Table 7).

\section{DISCUSSION}

In the current study, we aimed to compare the COVID-19 fear experienced by COVID-19 ICU staff and ICU staff and the effects of this fear on mental health. The study has three main contributions to the literature. First of all, our study; revealed that COVID-19 ICU staff working at the forefront of care and treatment of COVID-19 patients had higher levels of COVID-19 fear, depression, anxiety, and stress than ICU staff. We found a significant positive correlation between fear of COVID-19 and participants' depression, anxiety, and stress levels. Second, female gender, being a nurse, and working in COVID-19 ICU were associated with higher depression, anxiety, and stress scores. Finally, it revealed that as compared to ICU staff, COVID-19 ICU staff were approximate twice times more likely to experience anxiety and fear of COVID-19 and 3.5 times more likely to suffer from depression and stress.

The first COVID-19 case in Turkey was detected on March 9, 2020. The first death associated with COVID-19 was seen on March 17, 2020 (14). The Ministry of Health announced the daily status report of COVID-19 as of July 1,2020 . Turkey reported the daily number of new cases as 1 198, the number of newly hospitalized patients as 688, and the number of newly intubated patients as 52 (15). The Government of the Republic of Turkey took some national measures to prevent the spread of the disease: They gradually suspended flights to risky countries. They banned foreign nationals from entering the country. For cases with suspected infection, 14 days of isolation and symptom follow-up were enforced. Administrative leave was granted for staff with chronic illness. They restricted face-to-face education in schools. Temporarily stopped the work of recreation and entertainment venues. They reorganized the way institutions such as dormitories and nursing homes work. They took measures for public transportation and intercity buses. A weekend curfew was imposed in the country. Non-urgent surgical interventions were postponed. Besides scientific studies have been started on subjects such as virus isolation, vaccine, and drug therapy (14). In Turkey, COVID-19 vaccine applications started on January 14, 2021, with the approval of the Ministry of Health, primarily for healthcare workers. As of July 2020, when we conducted the research, vaccination of healthcare workers had not yet started (16). Restrictions affecting the flow of daily life and being unvaccinated may have negatively affected the fears and mental health of intensive care personnel.

When the current literature is examined, there are clinical studies conducted in different countries evaluating the fear, anxiety, depression, and stress levels of healthcare workers during the COVID-19 pandemic and related factors $(6,7,10,11,17-20)$. Ahorsu et al. (10) evaluated the effects of fear of COVID-19 on the mental health of the Iranian population. They showed that there was a significant positive correlation between fear of COVID-19 and depression and anxiety. COVID-19 fear levels of
Table 4. DASS-21 score distribution according to COVID-19 ICU and ICU

\begin{tabular}{lccc}
\hline & COVID-19 ICU & ICU & p \\
\hline Depression, n (\%) & & & \\
Normal & $48(53.3 \%)$ & $53(80.3 \%)$ & \\
Mild & $6(6.7 \%)$ & $2(3.0 \%)$ & \\
Moderate & $20(22.2 \%)$ & $3(4.6 \%)$ & $\mathbf{0 . 0 1 2}$ \\
Severe & $8(8.9 \%)$ & $7(10.6 \%)$ & \\
Extremely severe & $8(8.9 \%)$ & $1(1.5 \%)$ & \\
Anxiety, n (\%) & & & \\
Normal & $52(57.8 \%)$ & $49(74.2 \%)$ & \\
Mild & $16(17.8 \%)$ & $6(9.1 \%)$ & \\
Moderate & $12(13.3 \%)$ & $6(9.1 \%)$ & 0.302 \\
Severe & $3(3.3 \%)$ & $2(3.0 \%)$ & \\
Extremely severe & $7(7.8 \%)$ & $3(4.6 \%)$ & \\
Stress, n (\%) & & & \\
Normal & $52(57.8 \%)$ & $55(83.3 \%)$ & \\
Mild & $17(18.9 \%)$ & $6(9.1 \%)$ & \\
Moderate & $11(12.2 \%)$ & $2(3.0 \%)$ & $\mathbf{0 . 0 0 8}$ \\
Severe & $10(11.1 \%)$ & $3(4.6 \%)$ & \\
Extremely severe & $0(0.0 \%)$ & $0(0.0 \%)$ & \\
\hline DASS-21: depression anxiety stress scale, COVID-19 ICU: COVID-19 intensive care \\
unit, ICU: general intensive care unit
\end{tabular}

Table 5. Comparison the COVID-19 fear, depression, anxiety and stress between COVID-19 ICU and ICU staff

\begin{tabular}{lccc}
\hline & COVID-19 ICU & ICU & p \\
\hline FCV-19S & $21(17-25)$ & $19(12-23)$ & $\mathbf{0 . 0 2 2}$ \\
DASS-21 & & & \\
$\quad$ Depression & $6(2-16)$ & $4(2-8)$ & $\mathbf{0 . 0 1 1}$ \\
Anxiety & $4(2-10)$ & $2(0-6)$ & $\mathbf{0 . 0 0 2}$ \\
$\quad$ Stress & $12(7-17)$ & $8(4-12)$ & $<\mathbf{0 . 0 0 1}$ \\
\hline COVID-19 ICU: COVID-19 intensive care unit, ICU: general intensive care unit,
\end{tabular}

FCV-19S: fear of COVID-19 scale, DASS-21: depression anxiety stress scale

Table 6. Correlation coefficients between COVID-19 fear and DASS-21 depression, anxiety, and stress scores

\begin{tabular}{ccc}
\hline & FCV-19S & p \\
\hline DASS-21 & & \\
Depression & 0.399 & $\mathbf{0 . 0 4 4}$ \\
Anxiety & 0.456 & $\mathbf{0 . 0 1 9}$ \\
Stress & 0.418 & $\mathbf{0 . 0 3 3}$ \\
\hline
\end{tabular}

DASS-21: depression anxiety stress scale, FCV-19S: fear of COVID-19 scale

Table 7. Multivariate analysis of COVID-19 fear, depression, anxiety and stress between COVID-19 ICU and ICU

\begin{tabular}{lcc}
\hline Variables & OR (95\% CI) & p \\
\hline FCV-19S & 1 & \\
$\quad$ ICU & $1.65(0.986-2.452)$ & 0.077 \\
COVID-19 ICU & 1 & \\
DASS-21 Depression & & \\
$\quad$ ICU & $3.26(1.595-6.692)$ & $\mathbf{0 . 0 0 1}$ \\
$\quad$ COVID-19 ICU & 1 & \\
DASS-21 Anxiety & $1.98(1.010-3.892)$ & $\mathbf{0 . 0 4 7}$ \\
$\quad$ ICU & 1 & \\
$\quad$ COVID-19 ICU & 1 & \\
DASS-21 Stress & & \\
$\quad$ ICU & & \\
COVID-19 ICU & $3.61(1.688-7.750)$ & $\mathbf{0 . 0 0 1}$ \\
\hline
\end{tabular}

COVID-19 ICU: COVID-19 intensive care unit, ICU: general intensive care unit, OR: odds ratio, CI: confidence interval, FCV-19S: fear of COVID-19 scale, DASS-21: depression anxiety stress scale 
university students and graduates in Russia and Belarus Ahorsu et al. (10) slightly less than his work (19). In the study by García-Reyna et al. (20) where COVID-19 fear levels of Mexican medical staff were investigated, the FCV-19S median score was 19. In this study, they found that females had higher FCV-19S scores than males. In our study, we found a significant positive correlation between fear of COVID-19 and the depression, anxiety, and stress levels of intensive care workers. COVID-19 ICU staff had increased levels of COVID-19 fear compared to ICU staff. Similar to previous studies, we found that female staff members had higher COVID-19 fear levels than males. Previous studies had analyzed COVID-19 fear levels of the general population or healthcare professionals in a low-risk area. Interestingly, although our study included an intensive care unit with high-risk contact, similar to previous studies, we detected a moderate level of fear. The cause for this can be due to the relatively low incidence of COVID-19 cases in our region during the time we conducted the research. Also, it can be attributed to the effective execution of the COVID-19 pandemic preparation phase in our hospital and our country from March to July, when the first cases were recorded (21).

Previous pandemics have had adverse effects on the mental health of healthcare workers. Mental distress of personnel working in high-risk units such as severe acute respiratory syndrome (SARS) and Middle East respiratory syndrome-coronavirus (MERS-CoV) intensive care units have been associated with higher stress, anxiety, and fear than those working in low-risk hospital areas $(2,17)$. In our study, working in a high-risk COVID-19 ICU unit resulted in a significant increase in the COVID-19 fear, depression, anxiety, and stress levels of employees compared to the ICU unit. Lai et al. (17) reported that during the initial period of the COVID-19 outbreak, healthcare workers in China felt depression, anxiety, and stress $(50 \%, 44 \%$, and $71 \%$, respectively). During the COVID-19 pandemic Chew et al. (18) discovered moderate to very severe depression, anxiety, and stress $(50 \%, 55 \%$, and $42 \%$, respectively) in healthcare workers in Singapore and India. In our study, we found that $40 \%$ of COVID-19 ICU staff suffered from moderate to very severe depression, and $24 \%$ from anxiety and stress. Mental distress levels in our study were lower than those of previously reported studies $(17,18)$. We believe that there may be several reasons for this; increased mental preparedness of staff, the effectiveness of infection control measures, and reduced uncertainty at the onset of the pandemic. Greenberg et al. (22) investigated the mental status of COVID-19 intensive care staff in June-July 2020. They reported that $59 \%$ of the staff were in good mental health. Similarly, we found that more than half of the COVID-19 ICU staff had no mental health problems. However, they reported that $45 \%$ of the staff experienced at least one of post-traumatic stress disorder $40 \%$, severe depression $6 \%$, severe anxiety disorder $11 \%$, and alcohol consumption problems $7 \%$. The surveys we used were different from the ones they used. Nevertheless, our results showed that COVID-19 ICU staff suffered from higher severe to very severe depression, and our rates of stress and anxiety were similar ( $42 \%$ stress, severe to very severe depression, and anxiety disorder $17 \%$ and $11 \%$, respectively). In the SARS outbreak, Styra et al. (2) had found that the gender factor did not affect the mental health of healthcare professionals. In contrast, in the study conducted in the MERS-CoV outbreak, female nurses had significantly higher levels of anxiety and fear compared to their male counterparts (23). Another study conducted during the COVID-19 pandemic showed that gender affects mental health, especially nurses and females, experiencing more symptoms of depression, anxiety, insomnia, and distress (17). In our study; when both ICU staff were evaluated, it was found that the fear, depression, anxiety, and stress scores of females were higher than males. However female staff in COVID-19 ICU was more likely to experience mental distress than the ICU group. Previous studies have suggested that fluctuations in female's estrogen and progesterone levels may be the source of mood and anxiety disorders. Studies have revealed that females are more likely to experience psychological problems during periods of hormonal change (puberty, menopause, perimenstrual, and postpartum). Studies on males have shown that testosterone is a protective factor against anxiety and depression (24). It would be incomplete to look at this issue from a purely biological point of view. We think that these three structures will have an impact on mental health during the pandemic process since humans have biological, psychological, and social characteristics. Quarantine and social restrictions can trigger psychological distress (25). In addition, other studies have shown that females increased burden of unpaid labor and care in the household (daily housework, care of children, distance education process, care for family members during curfew, hygiene management, etc.) may be associated with poor mental health during the pandemic process (26).

In the previous SARS outbreak, Styra et al. (2) reported that nurses' risk of emotional distress was higher than other healthcare workers. Similarly, studies conducted during the COVID-19 pandemic have shown that nurses' psychological distress levels are higher than other healthcare professionals $(22,27)$. They also reported that in addition to being a nurse, the female gender also significantly increased psychological distress $(17,27)$. In our study, similar to previous studies, being a nurse, and female gender increased the depression, anxiety, and stress levels of COVID-19 ICU staff. The reason for the prevalence of mental distress among nurses may be that they play a front-line role in providing treatment and care for the patient. Nurses' working periods in the isolation department are longer than doctors and their direct contact with the patient can easily lead to fatigue and tension (27). Styra et al. (2) found that in the SARS epidemic, the work experience did not affect the mental status of healthcare workers. In our study, the anxiety and stress levels of the personnel with less than 10 years of working experience in COVID-19 ICU were slightly higher than the ICU group. Pandemic is a long process. The incidence of the disease varies depending on the localization in different periods. Our study is a cross-sectional study conducted in the specified period and it coincides with the end of the first wave of the pandemic in our region. It should be taken into consideration that the scores we have determined may vary in different periods of the pandemic. Although there are differences between ICU staff characteristics and work experiences, it may be a recommendation.

The success of newly developed treatment strategies and vaccination studies will also have an impact on fear and 
mental health. Therefore, we planned to repeat our research as the outbreak progressed. We intend to reevaluate the results of this study, which contributes to the current literature, with the results of our next study.

\section{CONCLUSION}

This study provides insight into the adverse mental effects of the COVID-19 pandemic on frontline intensive care staff. Increasing fear of COVID-19 led to an increase in intensive care workers' depression, anxiety, and stress values. The mental well-being of females, and nurses, working in the COVID-19 ICU should be protected to sustain the health workforce efficiently for a long time. Psychological support should be provided for intensive care staff. We think that this study will contribute to the Ministry of Health and hospital administrators to gain awareness of the mental problems of intensive care staff and to take corrective measures.

Ethics Committee Approval: The study was approved by the Clinical Research Ethics Committee of the Kırşehir Ahi Evran University (24.06.2020, 09-63).

Conflict of Interest: None declared by the authors.

Financial Disclosure: None declared by the authors.

Acknowledgements: The authors would like to thank Prof. Dr. Özkan Görgülü (Department of Biostatistics and Medical Informatics, Kırşehir Ahi Evran University Faculty of Medicine) for his assistance in the statistical analysis of the study.

Author Contributions: Idea/Concept: FÇ; Design: FÇ, RD; Data Collection/Processing: FÇ; Analysis/Interpretation: FÇ, RD; Literature Review: FÇ; Drafting/Writing: FÇ; Critical Review: FÇ, RD.

\section{REFERENCES}

1. who.int [Internet]. World Health Organization. Mental health and psychosocial considerations during the COVID-19 outbreak. 2020 [Cited: 2020 June 27]. Available from: https://www.who.int/docs/defaultsource/coronaviruse/mental-health-considerations.pdf.

2. Styra R, Hawryluck L, Robinson S, Kasapinovic S, Fones C, Gold WL. Impact on health care workers employed in high-risk areas during the Toronto SARS outbreak. J Psychosom Res. 2008;64(2):177-83.

3. Ho SM, Kwong-Lo RS, Mak CW, Wong JS. Fear of severe acute respiratory syndrome (SARS) among health care workers. J Consult Clin Psychol. 2005;73(2):344-9.

4. McAlonan GM, Lee AM, Cheung V, Cheung C, Tsang $\mathrm{KW}$, Sham PC, et al. Immediate and sustained psychological impact of an emerging infectious disease outbreak on health care workers. Can J Psychiatry. 2007;52(4):241-7.

5. Matsuishi K, Kawazoe A, Imai H, Ito A, Mouri K, Kitamura N, et al. Psychological impact of the pandemic (H1N1) 2009 on general hospital workers in Kobe. Psychiatry Clin Neurosci. 2012;66(4):353-60.
6. Shen X, Zou X, Zhong X, Yan J, Li L. Psychological stress of ICU nurses in the time of COVID-19. Crit Care. 2020;24(1):200.

7. Albott CS, Wozniak JR, McGlinch BP, Wall MH, Gold BS, Vinogradov S. Battle buddies: Rapid deployment of a psychological resilience intervention for health care workers during the COVID-19 pandemic. Anesth Analg. 2020;131(1):43-54.

8. Malhotra N, Gupta N, Ish S, Ish P. COVID-19 in intensive care. Some necessary steps for health care workers. Monaldi Arch Chest Dis. 2020;90(1):1284.

9. Wu PE, Styra R, Gold WL. Mitigating the psychological effects of COVID-19 on health care workers. CMAJ. 2020;192(17):E459-60.

10. Ahorsu DK, Lin CY, Imani V, Saffari M, Griffiths MD, Pakpour AH. The fear of COVID-19 scale: Development and initial validation. Int J Ment Health Addict. 2020; [Epub ahead of print]. doi: 10.1007/s11469-020-00270-8.

11. Satici B, Gocet-Tekin E, Deniz ME, Satici SA. Adaptation of the fear of COVID-19 scale: Its association with psychological distress and life satisfaction in Turkey. Int $\mathbf{J}$ Ment Health Addict. 2020; [Epub ahead of print]. doi: 10.1007/s11469-02000294-0.

12. Lovibond PF, Lovibond SH. The structure of negative emotional states: comparison of the depression anxiety stress scales (DASS) with the beck depression and anxiety inventories. Behav Res Ther. 1995;33(3):335-43.

13. Yılmaz Ö, Boz H, Arslan A. The validity and reliability of depression stress and anxiety scale (DASS-21) Turkish short form. Res Financial Econ Soc Sci J. 2017;2(2):78-91.

14. Demirbilek Y, Pehlivantürk G, Özgüler ZÖ, Alp Meşe E. COVID-19 outbreak control, example of ministry of health of Turkey. Turk J Med Sci. 2020;50(SI-1):489-94.

15. saglik.gov.tr [Internet]. Republic of Turkey Ministry of Health. COVID-19 information page. [Cited: 2020 July 1]. Available from: https://covid19.saglik.gov.tr/.

16. Yıldırım Baş F. The importance of vaccination in the pandemia and COVID-19 vaccination studies. Med J SDU. 2021;(ozelsayi-1):245-8.

17. Lai J, Ma S, Wang Y, Cai Z, Hu J, Wei N, et al. Factors associated with mental health outcomes among health care workers exposed to coronavirus disease 2019. JAMA Netw Open. 2020;3(3):e203976.

18. Chew NWS, Lee GKH, Tan BYQ, Jing M, Goh Y, Ngiam NJH, et al. A multinational, multicentre study on the psychological outcomes and associated physical symptoms amongst healthcare workers during COVID-19 outbreak. Brain Behav Immun. 2020;88:559-65.

19. Reznik A, Gritsenko V, Konstantinov V, Khamenka N, Isralowitz R. COVID-19 fear in Eastern Europe: Validation of the fear of COVID-19 scale. Int J Ment Health Addict. 2020; [Epub ahead of print]. doi: 10.1007/s11469-020-00283-3.

20. García-Reyna B, Castillo-García GD, BarbosaCamacho FJ, Cervantes-Cardona GA, Cervantes-Pérez E, Torres-Mendoza BM, et al. Fear of COVID-19 scale for hospital staff in regional hospitals in Mexico: a brief report. Int J Ment Health Addict. 2020; [Epub ahead of print]. doi: 10.1007/s11469-020-00413-x. 
21. Öğütlü H. Turkey's response to COVID-19 in terms of mental health. Ir J Psychol Med. 2020:37(3):222-5.

22. Greenberg N, Weston D, Hall C, Caulfield T, Williamson V, Fong K. Mental health of staff working in intensive care during COVID-19. Occup Med (Lond). 2021;71(2):62-7.

23. Bukhari EE, Temsah MH, Aleyadhy AA, Alrabiaa AA, Alhboob AA, Jamal AA, et al. Middle East respiratory syndrome coronavirus (MERS-CoV) outbreak perceptions of risk and stress evaluation in nurses. J Infect Dev Ctries. 2016;10(8):845-50.

24. McHenry J, Carrier N, Hull E, Kabbaj M. Sex differences in anxiety and depression: role of testosterone. Front Neuroendocrinol. 2014;35(1):4257.

25. Ar1 M, Duman T. COVID-19 and mental health. Duzce Med J. 2020;22(Special Issue):19-22.

26. Altun F. How the COVID-19 pandemic, the crisis of the century, impacted social life and women's socioeconomic status. Marmara Univ J Women Gend Stud. 2021;5(1):51-73.

27. Huang JZ, Han MF, Luo TD, Ren AK, Zhou XP. [Mental health survey of medical staff in a tertiary infectious disease hospital for COVID-19]. Zhonghua Lao Dong Wei Sheng Zhi Ye Bing Za Zhi. 2020;38(3):192-5. Chinese. 